\title{
Erratum to: Strategic Management of the Manufacturing Value Chain
}

\author{
Umit S. Bititci and Allan S. Carrie \\ University of Strathclyde, Glasgow
}

Erratum to:

U.S. Bititci and A.S. Carrie: (Eds.)

Strategic Management of the Manufacturing Value Chain

DOI: $10.1007 / 978-0-387-35321-0$

The book was inadvertently published with an incorrect name of the copyright holder. The name of the copyright holder for this book is: (c) IFIP International Federation for Information Processing. The book has been updated with the changes. 